\title{
Use of Learning Video Media to Improve Mathematics Learning Results About Space Building
}

\section{Ni'matul Machmudah}

SD Negeri Ori

mudzahaz@gmail.com

\section{Article History}

accepted 14/11/2020

approved $21 / 11 / 2020$

published 26/11/2020

\begin{abstract}
The purpose of this research is to improve mathematics learning result about space building of grade II. The research conducted was Classroom Action Research (PTK) with 3 cycles, the research place was the unit where the researcher taught. The results of the first cycle were $63.63 \%$ of students had passed the KKM, in the second cycle students who passed the KKM were $81.82 \%$ and in the third cycle $95.4 \%$ of the students passed the KKM. With an increase in the number of students who pass the KKM, the use of instructional video media can improve student learning outcomes in mathematics, especially about building space.
\end{abstract}

Keywords: learning video media, space building, learning results

\begin{abstract}
Abstrak
Tujuan Penelitian ini adalah meningkatkan hasil belajar matematika tentang bangun ruang kelas II. Penelitian yang dilakukan adalah Penelitian Tindakan Kelas (PTK) dengan 3 siklus, tempat penelitian adalah unit dimana peneliti mengajar. Hasil siklus I adalah $63,63 \%$ peserta didik telah lulus KKM, pada siklus II peserta didik yang lulus KKM sebanyak $81,82 \%$ dan pada hasil siklus III 95,45\% peserta didik lulus KKM. Dengan peningkatan jumlah peserta didik yang lulus KKM, maka Penggunaan Media Video Pembelajaran dapat meningkatkan hasil belajar peserta didik dalam mata pelajaran matematika khususnya tentang bangun ruang.

Kata kunci: media video pembelajaran, bangun ruang, hasil belajar
\end{abstract}

Social, Humanities, and Education Studies (SHEs): Conference Series https://jurnal.uns.ac.id/shes

p-ISSN 2620-9284

e-ISSN 2620-9292 


\section{PENDAHULUAN}

Pada umumnya anak usia sekolah dasar berkisar antara 6 atau 7 tahun sampai 12 atau 13 tahun. Piaget (dalam Heruman, 2007: 1) menyatakan bahwa anak usia SD berada pada fase operasional konkrit yaitu kemampuan dalam proses berpikir untuk mengoperasikan kaidah logika, meskipun masih terikat dengan objek yang bersifat konkrit. Pada hakikatnya anak akan tertarik pada hal yang disukainya serta berminat pada hal yang dikuasainya. Anak akan merasa senang terhadap kegiatan belajar apabila anak tertarik dan merasa nyaman dalam kegiatan belajar tersebut. Maka dari itu, menjadi tugas guru dan tanggung jawab guru untuk menciptakan kegiatan belajar yang sesuai dengan karakter peserta didik, memberikan minat belajar, memberikan rasa nyaman serta menyenangkan sehingga peserta didik tertarik terhadap kegiatan belajar.

Terdapat banyak disiplin ilmu yang diberikan pada jenjang pendidikan dasar salah satunya yaitu Matematika yang pada jenjang pendidikan SD kelas rendah terintegrasi dalam pembelajaran tematik sesuai kurikulum yang berlaku saat ini yaitu kurikulum 2013. Matematika menurut Ruseffendi (dalam Heruman, 2007: 1) adalah bahasa simbol; ilmu deduktif; ilmu tentang pola keteraturan dan struktur yang terorganisasi, mulai dari unsur yang tidak didefinisikan, ke unsur yang didefinisikan, ke aksioma atau postulat dan akhirnya ke dalil. Matematika pada hakikatnya adalah belajar konsep dan mencari hubungan antarkonsep dan strukturnya. Dalam pembelajaran Matematika yang abstrak dan perkembangan anak usia SD yang masih berada pada tahap operasional konkrit, peserta didik memerlukan media atau alat bantu pembelajaran sebagai alat untuk memvisualisasikan konsep maupun materi sehingga dapat memudahkan peserta didik menangkap pelajaran yang disampaikan oleh guru. Proses pembelajaran pada fase konkrit dapat melalui tahap konkrit, semi konkrit, semi abstrak, dan selanjutnya abstrak.

Hasil belajar adalah kemampuan yang diperoleh anak setelah melalui kegiatan belajar (Mulyono Abdurrahman, 2003: 37). Menurut A. J. Romiszowski (dalam Mulyono Abdurrahman, 2003: 38) Mengatakan bahwa "Hasil belajar merupakan keluaran (outputs) dari suatu sistem pemrosesan masukan (inputs)". Hasil belajar matematika materi bangun ruang kelas 2 SD Negeri Ori masih rendah. Hal tersebut dapat dilihat dari jumlah peserta didik yang tuntas pada muatan pelajaran matematika materi bangun ruang hanya 40,91\% dari Kriteria Ketuntasan Minimal (KKM) yaitu 70. Pembelajaran matematika materi bangun ruang pada penelitian ini menggunakan media video pembelajaran berdasarkan karakteristik peserta didik yang berada pada tahap operasional kongkrit. Dalam kondisi seperti sekarang ini, sangat diperlukan penggunaan media pembelajaran yang bisa menyalurkan informasi dengan jelas kepada peserta didik.

Media pembelajaran secara etimologis terdiri dari dua kata, yakni media dan pembelajaran. Kata media berasal dari bahasa latin yang merupakan bentuk jamak dari kata "medium" yang secara harfiah memiliki arti "perantara" atau "pengantar" pesan dari sumber pesan kepada penerima pesan (Heinich, 2002). Santyasa (2007, hlm. 3) menyatakan bahwa media digunakan dalam proses komunikasi, termasuk kegiatan belajar mengajar. Menurutnya, proses pembelajaran mengandung lima komponen komunikasi, yakni guru sebagai komunikator, bahan pembelajaran sebagai pesan, media pembelajaran sebagai pembawa pesan, peserta didik sebagai komunikan dan tujuan pembelajaran. Menurut H. Malik (1994), Pengertian Media Pembelajaran adalah segala sesuatu yang dapat digunakan untuk menyalurkan pesan (bahan pembelajaran), sehingga dapat merangsang perhatian, minat, pikiran dan perasaan. Banyak sekali media pembelajaran yang dapat digunakan sebagai alat bantu penyalur pesan, salah satunya yaitu media audio visual misalnya media video.

Video merupakan serangkaian gambar gerak yang disertai suara yang membentuk suatu kesatuan yang dirangkai menjadi alur, dengan pesan-pesan di 
dalamnya untuk ketercapaian tujuan pembelajaran yang disimpan dengan proses penyimpanan pada media pita atau disk (Arsyad, 2004:36 dalam Rusman dkk 2011:218). Video merupakan media audio visual yang menampilkan gerak (Sadiman, 2008:74).

Berdasarkan uraian di atas, maka pelaksanaan pembelajaran memerlukan kemampuan guru dalam memilih media pembelajaran yang sesuai dengan situasi dan karakteristik gaya belajar peserta didik dalam hal ini yaitu media video pembelajaran sehingga tercapai tujuan belajar yang salah satunya yaitu berdampak pada kenaikan hasil belajar peserta didik.

\section{METODE}

Penelitian yang dilakukan adalah Penelitian Tindakan Kelas dengan III siklus, Langkah-Langkah Penelitian Tindakan Kelas yang dilakukan adalah: 1) Mengidentifikasi dan Merumuskan Masalah. 2) Menganalisis Masalah. 3) Merumuskan Hipotesis Tindakan Kelas. 4) Merumuskan Rencana Tindakan. 5) Melaksanakan Tindakan. 6) Menganalisis dan Memaknai Data. 7) Membuat Laporan Hasil Penelitian. Penelitian ini dilaksanakan di kelas II SD Negeri Ori Kecamatan Kuwarasan Kabupaten Kebumen. Penelitian dilaksanakan selama tiga minggu. Dengan rincian, siklus pertama dilakukan pada 26 Oktober 2020 sampai dengan 4 November 2020, siklus kedua dilakukan pada 5 November 2020 sampai dengan 11 November 2020 dan siklus ketiga pada 17 November 2020 sampai dengan 23 November 2020. Teknik pengumpulan data yang dilakukan adalah Observasi dan Tes. Observasi yang dilakukan meliputi observasi pembelajaran matematika materi bangun ruang menggunakan media video pembelajaran dan observasi peserta didik selama pembelajaran. Teknik teks melalui tes evaluasi pada google form.

\section{HASIL DAN PEMBAHASAN}

Pelaksanaan siklus I dilaksanakan dalam 1 pertemuan dengan materi unsurunsur bangun ruang kubus dan balok. Pelaksanaan pembelajaran menggunakan video pembelajaran yang dibuat sendiri oleh peneliti dan diuanggah ke youtube. Pelaksanaan pembelajaran dengan media video pembelajaran pada siklus I dilaksanakan secara runtut mulai dari guru persiapan sebelum menyaksikan video pembelajaran, menyaksikan dan mengamati video pembelajaran, penguatan materi, pengamatan benda berbentuk bangun ruang di lingkungan sekitar dan mengkomunikasikan hasil diskusi. Kriteria ketuntasan minimal untuk muatan pelajaran matematika kelas II yaitu 70. Berikut ini merupakan perbandingan hasil belajar pada kondisi awal sebelum dilakukan tindakan dengan hasil siklus I.

Tabel 1. Perbandingan Kondisi Awal dan Hasil Belajar Siklus I

\begin{tabular}{ccccc}
\hline & \multicolumn{2}{c}{ Tuntas } & \multicolumn{2}{c}{ Tidak Tuntas } \\
& Jumlah & $\%$ & Jumlah & $\%$ \\
\hline Kondisi Awal & 9 & 40,91 & 13 & 59,09 \\
Siklus I & 14 & 63,63 & 8 & 36,36 \\
\hline
\end{tabular}


Berdasarkan tabel di atas, maka terjadi peningkatan dari kondisi awal sebelum tindakan dan pada siklus I. Pada kondisi awal sebelum dilakukan tindakan, jumlah peserta didik yang tuntas berjumlah 9 anak atau 40,91\% dan yang tidak tuntas berjumlah 13 anak atau 59,09\%. Dan pada siklus I terjadi peningkatan jumlah peserta didik yang tuntas yaitu 14 anak atau $63,63 \%$, sedangkan yang tidak tuntas berjumlah 8 anak atau $36,36 \%$. Terjadi peningkatan ketuntasan belajar peserta didik sebesar $22,72 \%$.

Berdasarkan refleksi siklus I, peneliti memutuskan untuk melaksanakan siklus II dengan materi pembelajaran yaitu unsur-unsur prisma segitiga dan limas. Kegiatan pembelajaran dengan menggunakan media video pembelajaran dilaksanakan sesuai rencana yang meliputi persiapan sebelum menyaksikan media video pembelajaran, menyaksikan dan mengamati video pembelajaran pertama tentang benda-benda berbentuk prisma segitiga dan limas, penguatan materi, diskusi kelompok, pengamatan benda-benda di sekitar, mengkomunikasikan hasil diskusi, menyaksikan dan mengamati video pembelajaran tentang unsur-unsur prisma segitiga dan limas, penguatan materi, melakukan diskusi, mengkomunikasikan hasil diskusi. Berikut merupakan tabel perbandingan hasil belajar siklus I dan siklus II.

Tabel 2. Perbandingan Hasil Belajar Siklus I dan Siklus II

\begin{tabular}{ccccc} 
& \multicolumn{2}{c}{ Tuntas } & \multicolumn{2}{c}{ Tidak Tuntas } \\
& Jumlah & $\%$ & Jumlah & $\%$ \\
\hline Siklus I & 14 & 63,63 & 8 & 36,36 \\
Siklus II & 18 & 81,82 & 4 & 18,18 \\
\hline
\end{tabular}

Berdasarkan tabel di atas, maka terjadi peningkatan dari hasil belajar siklus I dan siklus II. Pada hasil belajar siklus I, jumlah peserta didik yang tuntas berjumlah 14 anak atau $63,63 \%$ dan yang tidak tuntas berjumlah 8 anak atau $36,36 \%$. Dan pada siklus II terjadi peningkatan jumlah peserta didik yang tuntas yaitu 18 anak atau $81,82 \%$, sedangkan yang tidak tuntas berjumlah 4 anak atau $18,18 \%$. Terjadi peningkatan ketuntasan belajar peserta didik sebesar 18,19\%.

Berdasarkan refleksi siklus II, peneliti memutuskan untuk melaksanakan siklus III dengan materi pembelajaran yaitu unsur-unsur prisma segilima dan limas segilima. Kegiatan pembelajaran dengan menggunakan media video pembelajaran dilaksanakan sesuai rencana yang meliputi persiapan sebelum menyaksikan media video pembelajaran, menyaksikan dan mengamati video pembelajaran pertama tentang unsur-unsur prisma segilima dan limas segilima, penguatan materi, diskusi kelompok, menyaksikan dan mengamati video pembelajaran tentang menghitung unsur-unsur prisma segilima dan limas segilima, penguatan materi, melakukan diskusi, mengkomunikasikan hasil diskusi. Berikut merupakan tabel perbandingan hasil belajar siklus II dan siklus III. 
Tabel 3. Perbandingan Hasil Belajar Siklus II dan Siklus III

\begin{tabular}{ccccc} 
& \multicolumn{2}{c}{ Tuntas } & \multicolumn{2}{c}{ Tidak Tuntas } \\
& Jumlah & $\%$ & Jumlah & $\%$ \\
\hline Siklus II & 18 & 81,82 & 4 & 18,18 \\
Siklus III & 21 & $95,45 \%$ & 1 & 4,55 \\
\hline
\end{tabular}

Berdasarkan tabel di atas, maka terjadi peningkatan dari hasil belajar siklus II dan siklus III. Pada hasil belajar siklus II, jumlah peserta didik yang tuntas berjumlah 18 anak atau $81,82 \%$ dan yang tidak tuntas berjumlah 4 anak atau $18,18 \%$. Dan pada siklus III terjadi peningkatan jumlah peserta didik yang tuntas yaitu 21 anak atau $95,45 \%$, sedangkan yang tidak tuntas berjumlah 1 anak atau $4,55 \%$. Terjadi peningkatan ketuntasan belajar peserta didik sebesar 13,63\%.

Dari tiga siklus yang dilaksanakan dalam tiga pertemuan menunjukkan bahwa media video pembelajaran dapat meningkatkan hasil belajar matematika materi bangun ruang peserta didik kelas II SD Negeri Ori.

\section{SIMPULAN}

Penggunaan media pembelajaran berupa video, mampu meningkatkan hasil belajar peserta didik kelas II SD Negeri Ori materi bangun ruang pada muatan pelajaran matematika, sehingga capaian hasil belajar peserta didik juga meningkat. Hal tersebut dikarenakan penggunaan media dalam proses belajar mengajar membuat suasana belajar lebih menarik, menyenangkan dan mempermudah tercapainya pesan atau materi pelajaran. Berdasarkan hasil penelitian yang telah dilakukan, maka penggunaan media pembelajaran merupakan salah satu faktor penting dalam proses belajar mengajar, sehingga guru harus menguasai penggunaan media pembelajaran, bahkan harus bisa memilih media mana yang tepat. Guru juga mungkin akan dituntut membuat media pembelajaran sendiri, disesuakaian dengan keadaan sekolah dan keadaan peserta didik.

\section{DAFTAR PUSTAKA}

Arsyad, 2004:36 dalam Rusman dkk 2011:218 diakses dari http://meaningaccordingtoexperts.blogspot.com/2017/04/pengertian-mediavideo-pembelajaran.html. Diakses tanggal 20 Oktober 2020.

A. J. Romiszowski dalam Mulyono Abdurrohman. 2003. Pendidikan Bagi Anak Berkesulitan Belajar. Jakarta: Rineka Cipta.

Heinich, 2002 dalam Dr. Sandi Budi Irawan, M.Pd. Modul 6 Pendalaman Materi Pembelajaran di SD Berbasis TIK. Bandung: Kementerian Pendidikan dan Kebudayaan, 2019.

H. Malik (1994) dalam Dr. Sandi Budi Irawan, M.Pd. Modul 6 Pendalaman Materi Pembelajaran di SD Berbasis TIK. Bandung: Kementerian Pendidikan dan Kebudayaan, 2019.

Mulyono Abdurrohman. 2003. Pendidikan Bagi Anak Berkesulitan Belajar. Jakarta: Rineka Cipta. 
SHEs: Conference Series 3 (3) (2020) 863- 868

Piaget dalam Heruman. 2007. Model Pembelajaran Matematika di Sekolah Dasar. Bandung: PT.Rosydakarya.

Ruseffendi dalam Heruman. 2007. Model Pembelajaran Matematika di Sekolah Dasar. Bandung: PT.Rosydakarya.

Sadiman, 2008:74

diakses

dari http://meaningaccordingtoexperts.blogspot.com/2017/04/pengertian-mediavideo-pembelajaran.html.Diakses tanggal 20 Oktober 2020.

Santyasa (2007, hlm. 3) dalam Dr. Sandi Budi Irawan, M.Pd. Modul 6 Pendalaman Materi Pembelajaran di SD Berbasis TIK. Bandung: Kementerian Pendidikan dan Kebudayaan, 2019. 